\title{
Hennekam-Beemer syndrome
}

INSERM

\section{Source}

INSERM. (1999). Orphanet: an online rare disease and orphan drug data base.

Hennekam-Beemer syndrome. ORPHA:2135

Hennekam-Beemer syndrome is characterized by the association of skin mastocytosis (appearing as diffuse pigmentation), short stature, microcephaly, conductive hearing loss, and dysmorphic features. It has been described in only two (female) cases: one with normal mental development born to consang uineous parents and the other with severe psychomotor retardation born to unrelated parents. The mode of inheritance is most likely autosomal recessive. 